УДК 550.47

БИОГЕОХИМИЯ СЕРЫ В ДОННЫХ ОСАДКАХ ВОДНЫХ ОБЪЕКТОВ ГИДРОТЕРМАЛЬНОГО УРОЧИЩА ПЫМВАШОР

Кокрятская Н.М., Титова К.В., Вахрамеева Е.А., Попов С.С.

ФГБУН Федеральный исследовательский центр комплексного изучения Арктики имени академика Н.П. Лаверова Уральского отделения Российской академии наук, Архангельск, e-mail: nkokr@yandex.ru

В статье представлены результаты комплексного изучения биогеохимических процессов цикла серы по данным параметров сульфатредукции (накопления и трансформации форм реакционноспособного железа, содержания соединений восстановленной серы) в совокупности с данными по распределению органического вещества (OB) донных осадков (ДО) водных объектов урочища Пымвашор (двух озер, трех источников (холодных и горячих) и самого ручья Пымвашор). В настоящее время это единственное в континентальной Европе место, где на заполярных территориях действуют гидротермальные источники. Показано, что в ДО всех изученных водоемов протекает процесс бактериального восстановления сульфатов (сульфатредукция). Выявленные различия геохимических параметров сульфатредукции обусловлены спецификой протекающих в водоемах биогеохимических процессов, на которые, в свою очередь, наибольшее влияние оказывает литологический состав ДО, качественный состав органического вещества и его доступность для восстанавливающих сульфат микроорганизмов. В озерных отложениях при очень высоком количестве ОВ в составе торфянистых илов доминируют соединения лигнинно-гумусовой природы, трудноминерализуемые и поэтому малодоступные для бактериального сообщества. В осадках других водоемов органическое вещество имеет, скорее всего, смешанный характер, и количество присутствующего легкодоступного ОВ достаточно для протекания процесса сульфатредукции с одновременным накоплением соединений восстановленной серы. Помимо основных причин, влияющих на ход восстановления и окисления соединений серы, для данной экосистемы значимым является температурный фактор. В донных осадках незамерзающих водотоков увеличение доли легкодоступного органического вещества и постоянное наличие кислорода приводят к накоплению преимущественно кислоторастворимых моносульфидов железа и элементной серы, в отличие от малопроточных и промерзающих до дна озер, с доминированием в составе соединений восстановленной серы пиритной и органической составляющих.

Ключевые слова: Субарктика, гидротермальное урочище Пымвашор, донные осадки, биогеохимические процессы, восстановленная сера, органический углерод, реакционноспособное железо

\title{
BIOGEOCHEMISTRY OF SULFUR IN WATER BODIES OF THE PYMVASHOR HYDROTHERMAL TREATMENT
}

\author{
Kokryatskaya N.M., Titova K.V., Vakhrameeva E.A., Popov S.S. \\ N. Laverov Federal Center for Integrated Arctic Research Ural Branch RAS, \\ Arkhangelsk,e-mail:nkokr@yandex.ru
}

\begin{abstract}
The article presents the results of a comprehensive study of biogeochemical processes of the sulfur cycle based on the data of sulfate reduction parameters (the accumulation and transformation of reactive iron forms, the content of reduced sulfur compounds) in combination with data on the distribution of organic matter (OM) of bottom sediments (BS) of water bodies of the Pymvashor tract. It was shown that the process of bacterial reduction of sulfates (sulfate reduction) proceeds in BS of all studied water bodies. The revealed differences in the geochemical parameters of sulfate reduction are due to the specificity of biogeochemical processes occurring in water bodies, which, in turn, are most influenced by the lithological composition of BS, the qualitative composition of organic matter, and its availability for microorganisms reducing sulfate. In lacustrine sediments with a very high OM content, peaty silts are dominated by compounds of a lignin-humus nature, difficult to mineralize and therefore inaccessible to the bacterial community. In sediments of other water bodies, organic matter is most likely of a mixed nature, and the amount of readily available OM is sufficient for the process of sulfate reduction with the simultaneous accumulation of reduced sulfur compounds. In addition to the main reasons affecting the course of the reduction and oxidation of sulfur compounds, the temperature factor is significant for this ecosystem. In the bottom sediments of non-freezing watercourses, an increase in the proportion of readily available organic matter and the constant presence of oxygen lead to the accumulation of predominantly acid-soluble iron and elemental sulfur monosulfides, in contrast to lowflow and freezing lakes to the bottom, with the dominance of pyrite and organic components in the composition of reduced sulfur compounds.
\end{abstract}

Keywords: Subarctic, Pymvashor hydrothermal tract, bottom sediments, biogeochemical processes, reduced sulfur, organic carbon, reactive iron

Гидротермальное урочище Пымвашор (67010.300' с.ш., 6051.182' в.д.) находится на восточной окраине Большеземельской тундры. Несмотря на то, что пресноводные гидротермальные экосистемы широко распространены по всему земному шару, степень их изученности до сих пор крайне мала. Поскольку Пымвашор расположен в труднодоступной местности, его водная и наземная экосистема сохранилась до настоящего времени в практически ненарушенном виде. 
Гидротермальная система начала работать благодаря тектоническим процессам в глубоком прошлом. По результатам датирования термальных вод и травертина (известкового туфа) возраст для гидротермальной системы составляет как минимум 13.9 тыс. лет [1]. В районе урочища многолетнемерзлые породы отсутствуют, хотя сам объект находится в пределах зоны распространения многолетнемерзлых пород.

Урочище Пымвашор расположено в долине ручья Пымвашор, в 3,7 км по течению до его впадения в реку Адзьву (бассейн реки Печеры), представляет собой широкий и протяженный лог тектонического происхождения [2]. Протяженность ручья Пымвашор 21 км, максимальная ширина - 20-30 м; скорость течения - 0,3-0,5 м/с; глубина - от 0,2 м на перекатах до нескольких метров в омутах, дно каменистое, местами песчаное, на перекатах галечниковое; среднегодовая температура воды $5^{\circ} \mathrm{C}$ [2]. Всего в урочище насчитывается 13 действующих минерально-термальных источников: 8 горячих источников с температурой воды $20,3-28,5^{\circ} \mathrm{C}$ (суммарный расход вод 25,6 л/с) и 5 холодных карстовых источников с температурой около $1,2-6,0^{\circ} \mathrm{C}$ (суммарный расход вод 6,1 л/с) [2].

Вследствие пониженного относительно водораздела положения долины ручья Пымвашор и одновременного изгиба его русла на местности образуются участки одновременно хорошо защищенные от ветра и подогреваемые теплыми водами гидротерм. Азональная теплообеспеченность таких участков устойчиво сохраняется на протяжении сотен и тысяч лет. Поскольку источники и район их впадения в ручей Пымвашор зимой не покрываются льдом, то в зоне действия гидротерм не проявляется и сезонное промерзание грунтов - обеспечивается постоянство условий обитания и сохраняют активность почвенная биота, а также бентосные сообщества в водных объектах [2].

Из-за своей удаленности источники гидротермальной системы Пымвашор долгое время оставались недостаточно изученными. Расширенные научно-исследовательские работы в урочище были проведены сотрудниками Института экологических проблем Севера УрО РАН (в настоящее время ФГБУН ФИЦКИА УрО РАН) с 2009 по 2012 г. (в разные сезоны года). Были выполнены ландшафтно-гидрологическое зонирование и функциональное изучение экосистем, проведены микроклиматические, почвенно-криологические, эколого-физиологические, популяционные и прочие исследования, результаты которых представлены в целом ряде работ и обобщены в монографии [2]. Так, например, установлено, что источники и район их впадения в ручей Пымвашор зимой не замерзают. А благодаря особенностям рельефа и отепляющего воздействия горячих источников, на территории урочища имеются участки с повышенной теплообеспеченностью, где создаются условия для развития и функционирования почвенной биоты и бентоса, а также специфических растительных и животных сообществ.

Таким образом, с одной стороны гидротермальная система Пымвашор представляет пример очень высокой устойчивости к внешним климатическим воздействиям, а с другой - отличается очень высокой стабильностью условий среды. Все это накладывает отпечаток на элементы биогеохимических процессов, протекающих в водных объектах этого уникального природного объекта. Одним из основных процессов восстановительного диагенеза донных осадков является бактериальная сульфатредукция. В ходе этого процесса происходит сопряжение циклов таких геохимически подвижных элементов, как углерод, сера и железо. Целью настоящего исследования являлось изучение геохимических параметров сульфатредукции (содержание соединений восстановленной серы, накопление и трансформация форм реакционноспособного железа) в совокупности с данными по распределению органического вещества донных осадков водных объектов субарктического урочища Пымвашор.

\section{Материалы и методы исследования}

Пробы донных осадков для исследования отобраны в ноябре 2009 г. и сентябре 2010 г. в ходе Северной комплексной экспедиции Института экологических проблем Севера УрО РАН (ныне ФГБУН ФИЦКИА УpO PAH).

В зимний период (ноябрь) 2009 г. территория урочища Пымвашор была покрыта снегом, а большая часть акватории водотоков - льдом. Хотя в районах выхода термальных вод образуются полыньи, грунты на этих участках в основном были галечными и валунными - наиболее широко распространенными в пымвашорских водотоках. Поэтому поиск мест отбора донных отложений представлял известные трудности, вследствие чего было отобрано всего несколько проб с поверхности дна водотоков. В теплый период (сентябрь) 2010 г. пробы отбирали с помощью ударной прямоточной 
грунтовой трубки с внутренним диаметром 110 мм и длиной 1 м. Сразу после отбора керны ДО были последовательно разделены на слои и в виде образцов герметично упакованы в пластиковые пакеты. Во всех случаях длина отобранных кернов (колонок) определялась глубиной залегания коренных пород, в которые уткнулся пробоотборник.

Географическое место отбора проб фиксировалось с помощью спутникового определителя координат GPS навигатора.

Пробы были отобраны в следующих водоемах и водотоках урочища Пымвашор.

Озеро LPYM-1 расположено выше по течению ручья Пымвашор, на его левом берегу (за каменистой грядой), вне действия гидротерм урочища (площадь $\sim 400 \mathrm{~m}^{2}$, глубина 1-2 м). Колонка донных осадков (длиной 15 см) отобрана в точке с координатами N $67^{\circ} 09^{\prime} 39.79 "$, E 6051'34.16". Отобранные осадки довольно однородны и представлены темным волокнистым илом с остатками растительности и характерным запахом гниения.

Озеро LPYM-2 расположено в центре урочища на правом берегу ручья Пымвашор (площадь $\sim 130 \mathrm{~m}^{2}$, глубина 1-2 м). Колонка донных осадков (длиной 36 см) отобрана в точке с координатами N $67^{\circ} 09^{\prime} 51.38 "$, Е $60^{\circ} 51^{\prime} 10.29 "$. Визуально донные осадки четко стратифицированы: верхние 15 см представлены илом темного цвета с включениями волокон органического вещества (торфа, растительных остатков), в то время как нижележащие слои - илистые, темносерого цвета с примесью песка.

Питьевой ручей (AR-1) - самый мощный из холодных источников Пымвашорского лога. Он вытекает из трещины в скале и впадает в р. Пымвашор по правому берегу. Длина ручья составляет 175,6 м; расход воды - 4,2 л/с; в зимний период на всем протяжении ручей не замерзает. Колонка донных осадков длиной 51 см отобрана в среднем течении ручья в точке с координатами N $67^{\circ} 09^{\prime} 55.48^{\prime \prime}$ Е 6051'11.37". Визуально колонка неоднородна, осадки представляли собой темный волокнистый ил с глиной и растительными остатками (веточки).

«Омут» - участок в пределах одной из глубоководных и широких частей основного русла ручья Пымвашор, на выходе из лога. Колонка донных осадков длиной 24 см отобрана в точке с координатами N $67^{\circ} 09^{\prime} 57.72^{\prime \prime}$, E $60^{\circ} 51^{\prime} 04.64 "$. Отобранные осадки визуально однородны и представлены темными глинистыми илами с незначительными включениями мелких камней, осколков ракушки и растительности.
По правому берегу Пымвашора расположен самый крупный источник урочища (температура воды на его выходе $28,5^{\circ} \mathrm{C}$, расход воды 14 л/с), зарегулированный искусственно созданным бассейном. Проба отобрана в термальном болотце рядом с ним (R-3) в точке с координатами N 670 10.177', E $60^{0} 51.335^{\prime}$. Осадок представляет собой однородную черную жидкую илистую массу с остатками растительности.

В русле Горячего ручья (II-all), в который объединяются четыре источника Горячей горы (температуры вод в горлах разных источников составляют $25,7-27,4^{\circ} \mathrm{C}$; суммарный расход вод этой группы - 7,7 л/с), проба отобрана в точке с координатами $\mathrm{N} 67^{0} 10.300^{\prime}$, Е 6051.182'. Осадок представляет собой крупноватый серый заиленный песок с небольшим количеством растительных остатков; много мелких камешков (травертины, известняк) и осколков раковин моллюсков.

Гранулометрический состав донных осадков был определен по методике [3]. Общий и органический углерод определяли на CHN-анализаторе фирмы «Хьюлетт Паккард» методом сухого сожжения с последующим газохроматографическим разделением продуктов пиролиза. Реакционноспособное железо извлекали из осадка натуральной влажности экстракцией $3.5 \mathrm{~N}$ $\mathrm{H}_{2} \mathrm{SO}_{4}$, затем из аликвоты полученного раствора определяли железо (III) йодометрическим титрованием; железо (II) - из другой аликвоты дихроматным методом. Для определения различных форм серы использовали метод систематического фазового анализа (использование одной пробы осадка), разработанный в Институте океанологии.

\section{Результаты исследования и их обсуждение}

\section{Гидрохимическая характеристика водных объектов урочища Пьмвашор}

Согласно данным [2] воды всех водотоков урочища являются слабоминерализованными - их общая минерализация составляет 0,6-1,9 г/л. Величина показателя $\mathrm{pH}$ воды минерально-термальных источников, впадающих в ручей Пымвашор, и самого ручья (в пределах урочища и до его впадения в р. Адзьву) изменяется в диапазоне 7,6-8,3. Эти значения несколько выше по сравнению с более кислыми водами различных водоемов тундровой зоны [4].

По ионному составу (таблица) воды как термальных, так и карстовых источников 
по классификации Алекина относятся к хлоридно-натриевым. При этом из-за разбавления вод холодных источников поверхностными и атмосферными водами в них несколько повышена доля гидрокарбонатов. В целом для вод всех водотоков урочища характерно высокое насыщение кислородом, незначительное содержание биогенных соединений азота и фосфора, органических веществ [2].

В отличие от водотоков воды обоих исследованных озер относятся к гидрокарбонатному классу группы кальция (таблица). Минерализация в них очень низкая $(0,04$ 0,2 мг/л); а по уровню рН $(6,2-6,3)$ они более кислые по сравнению с водами водотоков, что типично для водоемов тундры, т.е. эти озера можно отнести к типично тундровым. По данным [2] в озерных водах зафиксировано повышенное по сравнению с водами источников содержание железа, что также подтверждает правомерность отнесения этих водоемов к типично тундровым, в питании которых наряду с атмосферными осадками значительную роль играют воды, поступающие с заболоченного водосбора.

В осадках обоих озер была определена скорость осадконакопления по ${ }^{210} \mathrm{~Pb}$. Для отложений более крупного из них - 03. LPYM-1, так же как ранее для обширного, но мелководного оз. Талатинское, расположенного на острове Вайгач [5], определить её нам не удалось, что, скорее всего, является следствием перемешивания слоев донных отложений этих водоемов в ходе сезонного замерзания - оттаивания. В о3. LPYM-2 она составила 2 мм/год [6].

\section{Гранулометрический анализ}

По данным гранулометрического анализа верхний слой осадков 03. LPYM-1 представлен пелито-алевритовым илом (доля алевритовой фракции 57 \%), нижележащие-алевропелитом, переходящим в грубодисперсный песчанистый алеврит на нижнем горизонте. Донные отложения ст. LPYM-2 визуально четко стратифицированы: поверхностные слои (0-6 см) являются торфянистым пелито-алевритовым илом с включениями растительных остатков, нижележащие осадки (до глубины 15 см) относятся к алевро-пелитам, а более глубокие слои (15-36 см) к песчаным алевритам при практически одинаковом содержании алевритовой и песчаной фракций -45 и $47 \%$ соответственно.

В ДО водотоков чаще доминируют более грубодисперсные фракции (рис. 1), содержание которых максимально в осадках «Омута», представленных песчано-алевритовым глинистым илом с включением мелких камешков и осколков раковин. Содержание грубодисперсной фракции максимально в отложениях Горячего ручья, представленных среднезернистым заиленным песком с большим количеством мелких камешков (травертины, известняк) и осколков раковин моллюсков. В отличие от них грубодисперсная фракция осадков, отобранных в омуте, в Питьевом ручье и в озеpe LPYM-2 представлена темным волокнистым илом с растительными остатками (в основном фрагментами веток кустарников) на разных стадиях разложения.

Среднее содержание основных ионов водных объектов урочища Пымвашор

\begin{tabular}{|l|c|c|c|c|c|c|c|c|}
\hline \multicolumn{1}{|c|}{ Место отбора проб } & & $\mathrm{Cl}^{-}$ & $\mathrm{SO}_{4}^{2-}$ & $\mathrm{HCO}_{3}^{-}$ & $\mathrm{K}^{+}$ & $\mathrm{Na}^{+}$ & $\mathrm{Ca}^{2+}$ & $\mathrm{Mg}^{2+}$ \\
\hline \multirow{2}{*}{ В среднем горячие источники } & \%-экв & 83,31 & 6,93 & 9,76 & 0,22 & 67,26 & 22,03 & 10,31 \\
\cline { 2 - 9 } & мг/л & 663,0 & 74,5 & 133,4 & 2,35 & 421,9 & 120,2 & 34,3 \\
\hline \multirow{2}{*}{ В среднем холодные источники } & $\%$-экв & 61,02 & 7,96 & 31,02 & 0,34 & 64,53 & 22,59 & 12,55 \\
\cline { 2 - 9 } & мг/л & 185,8 & 32,8 & 162,3 & 1,45 & 161,0 & 49,0 & 16,3 \\
\hline \multirow{2}{*}{ Термальный источник «Бассейн» } & \%-экв & 84,75 & 6,78 & 8,47 & 0,20 & 70,99 & 19,48 & 9,33 \\
\cline { 2 - 9 } & мг/л & 930 & 102 & 162 & 2,67 & 570 & 136 & 39,1 \\
\hline \multirow{2}{*}{ Горячий ручей } & \%-экв & 82,74 & 6,96 & 10,29 & 0,29 & 77,28 & 13,14 & 9,29 \\
\cline { 2 - 9 } & мг/л & 701 & 80,9 & 152 & 3,71 & 593 & 87,7 & 37,2 \\
\hline \multirow{2}{*}{ Питьевой ручей } & \%-экв & 55,81 & 6,32 & 37,87 & 0,40 & 74,52 & 11,07 & 14,00 \\
\cline { 2 - 9 } & мг/л & 168 & 26,1 & 214 & 1,45 & 178 & 36,7 & 16,6 \\
\hline \multirow{2}{*}{ Ручей ПВШ, (Омут) } & \%-экв & 67,66 & 6,75 & 25,58 & 0,32 & 71,65 & 15,08 & 12,96 \\
\cline { 2 - 9 } & мг/л & 217 & 29,7 & 143 & 1,59 & 212 & 38,8 & 20,0 \\
\hline \multirow{2}{*}{ Озеро LРYM-1 } & \%-экв & 15,34 & 4,23 & 80,43 & 2,99 & 26,57 & 50,73 & 19,71 \\
\cline { 2 - 8 } & мг/л & 11,1 & 4,14 & 100 & 2,08 & 10,9 & 18,1 & 4,22 \\
\hline \multirow{2}{*}{ Озеро LРYM-2 } & \%-экв & 13,08 & 1,30 & 85,62 & 0,68 & 2,72 & 79,00 & 17,61 \\
\cline { 2 - 8 } & мг/л & 10,4 & 1,40 & 117 & 1,02 & 4,42 & 61,1 & 8,17 \\
\hline
\end{tabular}




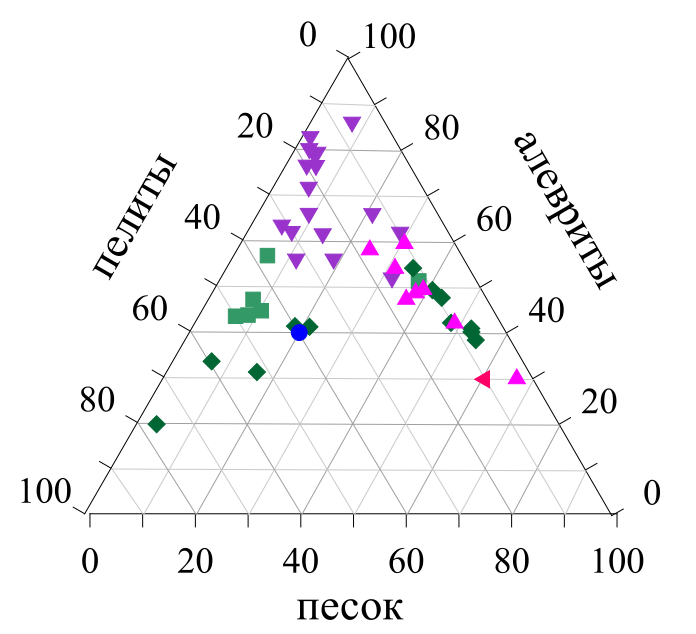

ст.LPYM -1

cr.LPYM - 2

$\checkmark$ Питьевой ручей

$\triangle$ омут

- Бассейн

4 Горячий ручей

Рис. 1. Трехкомпонентная диаграмма рассеивания гранулометрического состава донных отложений водных объектов урочища Пымвашор

\section{Органический углерод}

Наиболее высокое содержание органического углерода $\left(\mathrm{C}_{\text {opp }}\right)$ характерно для илистых отложений обоих озер (первые $12-15$ см) и Питьевого ручья (здесь и далее концентрации даны в расчете на сухой осадок): 18,7-24,4\% для оз. LPYM-1; 32,0$43,0 \%$ для 03. LPYM-2; 6,8-29,5\% для Питьевого ручья. Что представляется вполне закономерным, поскольку в их составе визуально присутствовал торф, содержание органического вещества в котором может достигать $80-90 \% \quad(40-45 \%$ в пересчете на органический углерод). В обоих озерах при переходе к нижележащим слоям (серый глинистый ил с примесью песка) содержание $\mathrm{C}_{\text {op }}$ резко уменьшается - до 5,94\% в оз. LPYM-1 и $0,41-1,17 \%$ в оз. LPYM-2. В керне осадков, отобранных в русле Питьевого ручья, распределение $\mathrm{C}_{\text {орг }}$ имеет слоистый характер - при среднем содержании $\mathrm{C}_{\text {орг }} 11,2 \%$, горизонты, где его количество более $10-15 \%$, перемежаются со слоями, где оно немногим более $1 \%$.

В отличие от ДО этих водоемов, распределение $\mathrm{C}_{\text {орг }}$ в колонке, отобранной на ст. «омут» более однородно - при среднем значении $0,58 \%$ разброс значений не выходит за границы интервала $0,41-0,64 \%$. При этом его доля в общем содержании углерода $\left(\mathrm{C}_{\text {обш }}\right)$ уменьшается от $65,7 \%$ в поверхностных осадках до 19,3\% в нижних слоях керна. Столь же невысоко количество ОВ в осадках Горячего ручья - 0,40\% (20,6\% от $\left.\mathrm{C}_{\text {обш }}\right)$. Доминирование карбонатной составляющей в отложениях этих водотоков представляется вполне закономерным, учитывая их вещественный состав. Напротив, в осадках обоих озер и Питьевого ручья вклад органической составляющей составляет в среднем $81,5 \%$ от $\mathrm{C}_{\text {об̆ }}(65,2-99,3 \%)$, лишь незначительно изменяясь в пределах длины кернов. В илистых отложениях термального болотца (ст. R-3), отобранных дночерпателем, содержание $\mathrm{C}_{\text {орг }}$ составляет $1,95 \%\left(66,3 \%\right.$ от $\left.\mathrm{C}_{\text {общ }}\right)$.

\section{Реакиионноспособное железо}

Если органическое вещество можно назвать движущей силой сульфатредукции, как и других восстановительных процессов, то реакционноспособное железо - это основной компонент, связывающий образующийся сероводород. С другой стороны, известно, что процесс восстановления Fe (III) значительно опережает сульфатредукцию в окислительно-восстановительных процессах диагенеза. Содержание реакционноспособного железа $\left(\mathrm{Fe}_{\text {реаки }}\right)$, т.е. наиболее подвижная в процессах диагенеза часть общего количества железа осадков, не только определяет уровень накопления в ДО восстановленной серы, но по соотношению его форм можно судить о направленности протекающих в ДО редокс-процессов.

Содержание реакционноспособного железа в ДО исследованных водоемов изменяется в широком интервале концентраций от 0,37 до $7,96 \%$. Минимальные значения этого показателя отмечены в нижних горизонтах колонки отложений озера LPYM-2. Столь же невелико содержание $\mathrm{Fe}_{\text {реакц }}$ 
в ДО Горячего ручья - 0,46\%. Наиболее высокое содержание $\mathrm{Fe}_{\text {реак }}$ отмечено в осадках ст. «омут» $-6,33 \%(5,52-7,96 \%)$, что, скорее всего, связано с осаждением на этом гидрологически более спокойном и относительно более глубоком участке русла ручья Пымвашор железа, поступающего с водами как холодных, так и горячих источников. Среднее содержание $\mathrm{Fe}_{\text {eан }}$ в осадках станций AR-1, R-3, LPYM-1 и LPYM-2 сопоставимо (рис. 2) и изменяется в интервале от 0,78 до 3,29\%. Можно отметить, что в целом высокое содержание железа (ожелезненность) характерно для пымвашорских источников - о наличии рыжей взвеси на камнях и подводных растениях сообщают практически все исследователи урочища, начиная с его первых научных описаний [2].

В верхних органогенных осадках обоих озер реакционноспособное железо представлено преимущественно окисленной формой - в среднем 54,4\% и 61,5\% от Fe соответственно для LPYM-1 и LPYM-2. В нижних горизонтах при изменении вещественного состава в озерных осадках начинает доминировать железо (II) (карбонаты, фосфаты, силикаты, оксиды, гидроксиды, сульфиды) - 65,3 и в среднем 54,5\%, соответственно для 1-го и 2-го озера. В пределах исследованной толщи отложений всех водотоков также доминирует более восстановленная форма реакционноспособного железа: $75,0 \%$ на ст. омут; 79,8\% в осадках Питьевого ручья и 77,8 \% от $\mathrm{Fe}_{\text {реакц }}$ в ДО Горячего ручья.

Можно выделить распределение форм

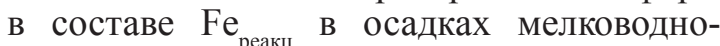
го термального болотца, расположенного вблизи наиболее мощного горячего источника «Бассейн» [2], где при довольно значительном общем содержании $\mathrm{Fe}_{\text {реакш }}(2,85 \%)$ практически полностью отсутствует его окисленная часть Fe (III).
Соединения восстановленной серы

Сера, обнаруженная в осадках, представлена серой сульфатов (по методике это сульфаты иловой и/или наддонной воды и сульфаты твердой фазы осадка) и восстановленной серой, образованной продуктами трансформации сероводорода, образовавшегося в процессе сульфатредукции.

Содержание общей восстановленной серы ( $\Sigma \mathrm{SH} 2 \mathrm{~S})$ максимально в осадках Питьевого ручья (0,37-2,28\%; в среднем $1,33 \%)$ и озера LPYM-1 (0,58-2,56\%; в среднем $1,74 \%$ ), где она преимущественно (67,8 и $63,6 \%$ от $\Sigma \mathrm{S}_{\mathrm{H} 2 \mathrm{~S}}$ соответственно) представлена органической формой, т.е. серой, связанной с лигнинно-гумусовым комплексом ОВ осадков (рис. 3). Не менее значителен вклад органической серы (в среднем $78,2 \%$ от $\Sigma \mathrm{SH} 2 \mathrm{~S}$ ) в отложениях озера LPYM-2, при том, что в абсолютных значениях её содержание на порядок ниже $(0,10 \%)$, чем в осадках вышеперечисленных водоемов. При сопоставимом с ними количестве ОВ в илистых осадках озера LPYM-2, процесс бактериального восстановления сульфатов идет гораздо менее интенсивно, что объясняется большей недоступностью ОВ для микроорганизмов. Подтверждением аллохтонной природы этого ОВ является преобладание в его составе (более $90 \%$ от $\mathrm{C}_{\text {орг }}$ ) гуминовых веществ. Можно предположить, что в отложениях Питьевого ручья и озере LPYM-1 в составе органического вещества, скорее всего, все же имеется достаточное количество лабильных соединений, что в совокупности с повышенным количеством сульфатов (таблица), способствует более активному протеканию сульфатредукции и, как следствие, большему накоплению восстановленной серы преимущественно в составе пирита.

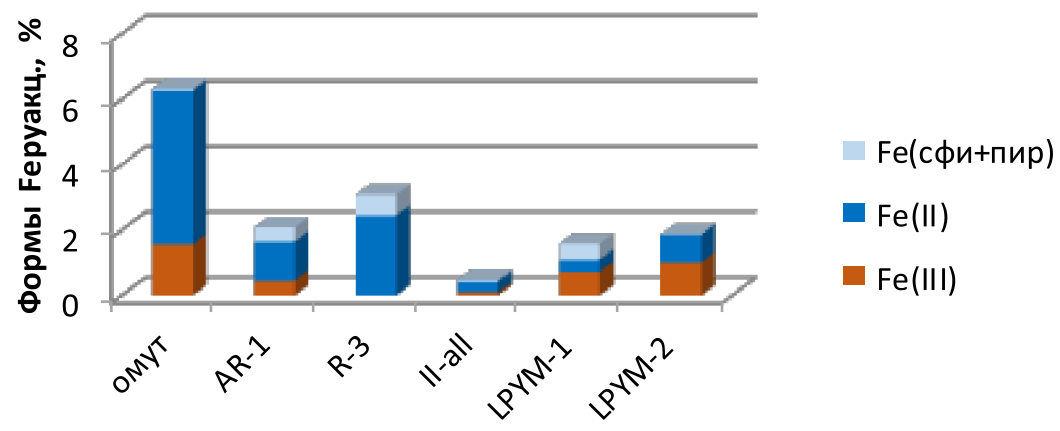

Рис. 2. Распределение форм реакционноспособного железа в ДО водных объектов урочища Пымвашор 


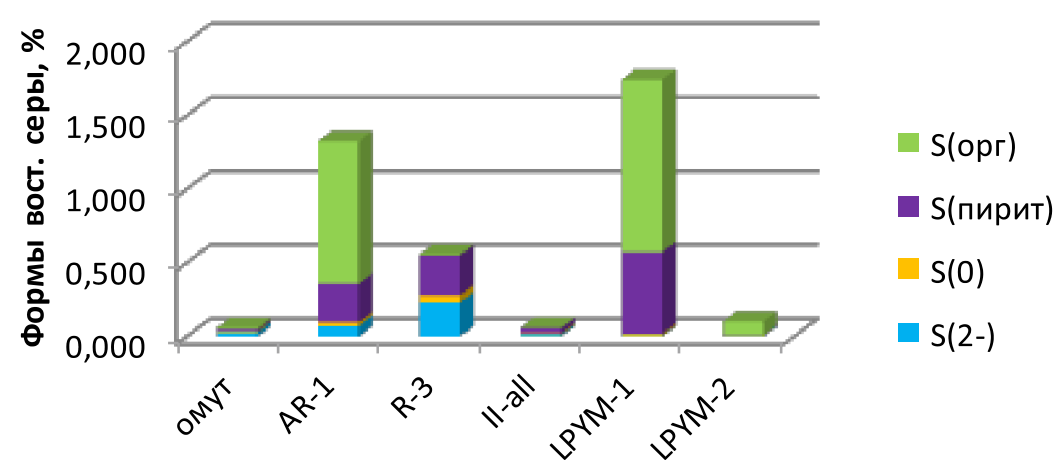

Рис. 3. Распределение форм восстановленной серы в ДО водных объектов урочища Пымвашор

В ДО «Омута» и Горячего ручья содержание $\Sigma \mathrm{SH} 2 \mathrm{~S}$ сопоставимо и крайне мало - в среднем 0,06 и $0,061 \%$ соответственно. При этом, уже начиная с верхних горизонтов, основной вклад в $\Sigma \mathrm{SH} 2 \mathrm{~S}$ вносят сульфидные (сумма моносульфидов и пирита) формы - 67,2 и $80,3 \%$ от $\Sigma \mathrm{S}_{\mathrm{H} 2 \mathrm{~s}}$ соответственно. Содержание сульфидных форм серы, максимально и в черных илистых осадках термального болотца, причем как в абсолютных концентрациях (0,50\%), так и по вкладу в $\Sigma \mathrm{SH} 2 \mathrm{~S}-90,1 \%$ от суммы форм. Можно отметить, что во всех четырех проточных незамерзающих водотоках в составе сульфидных форм не только значима, но и высока доля кислоторастворимых моносульфидов железа, что совсем не характерно для озерных отложений.

Вклад элементной серы в общее накопление восстановленной серы в ДО обоих озер крайне незначителен $-0,32-0,78 \%$ от $\Sigma \mathrm{SH} 2 \mathrm{~S}$; что отличает их от проточных водоемов, где особенно в верхних горизонтах ДО он изменяется от 1,72\% в Питьевом ручье до $8,99 \%$ в «бассейне» и $13,1-14,7 \%$ от $\Sigma \mathrm{SH} 2 \mathrm{~S}$ в «омуте» и Горячем ручье.

Представляло интерес сравнить накопление в осадках восстановленной серы как с содержанием в них ОВ, так и с содержанием сульфатов в водах исследованных водоемов. Как известно, именно эти показатели определяют интенсивность процесса сульфатредукции в ДО. В озерных отложениях не выявлено согласованности в накоплении в осадках восстановленной серы и содержанием в них органического углерода $(\mathrm{r}=0,28$ при $\mathrm{n}=17)$, напротив, для отложений водотоков, эта взаимосвязь проявилась $(\mathrm{r}=0,78$ при $\mathrm{n}=25)$. И этот факт может свидетельствовать о существовании различий в качественном составе ОВ этих водоемов. Как не раз упоминалось выше, в озерных отложениях при очень высоком количестве OB в составе волокнистых торфянистых илов доминируют соединения лигнинно-гумусовой природы, трудноминерализуемые и поэтому малодоступные для бактериального сообщества. В осадках других водоемов органическое вещество имеет, скорее всего, смешанный характер и количество присутствующего в них лабильного ОВ достаточно для протекания процесса сульфатредукции с одновременным накоплением соединений восстановленной серы. Кроме того, все эти водотоки (и термальное болотце около бассейна в том числе) не покрываются льдом и не замерзают в течение всего холодного периода [2] в отличие от обоих озер, которые вследствие небольшой глубины промерзают до дна. Даже в зимний период в них продолжаются продукционные процессы, а в верхних слоях незамерзающих отложений протекают процессы аэробной деструкции ОВ, обеспечивающие анаэробное бактериальное сообщество лабильными органическими соединениями.

Второй причиной различной интенсивности процесса сульфатредукции может быть различная его обеспеченность сульфатами. Выявлена неплохая взаимосвязь между содержанием в воде сульфатов и накоплением в ДО восстановленной серы (усредненные значения) с коэффициентом корреляции равным 0,88 (при $\mathrm{n}=6$ ). Можно отметить, что, скорее всего, именно обеспеченность сульфатами накладывает отпечаток на формирование $\Sigma \mathrm{SH} 2 \mathrm{~S}$ в озерных осадках. При сопоставимых данных по содержанию в ДО обоих озер органического вещества, содержание сульфатов в воде и донных отложениях оз. LPYM-1 значительно выше, чем в о3. LPYM-2 - в 3 и 40 раз соответственно. Исходя из анализа гидрохимических показателей, о3. LPYM-2 явля- 
ется типично тундровым и не испытывает влияния источников урочища. Повышенное количество сульфатов в воде и ДО территориально независимого от урочища озера LPYM-1, скорее всего, является следствием влияния холодных карстовых вод, многочисленные выходы которых отмечены и за пределами урочища.

\section{Заключение}

Выявленные в результате проведенного исследования различия геохимических параметров сульфатредукции в донных отложениях водоемов, расположенных в пределах гидротермального урочища Пымвашор обусловлены спецификой протекающих в них биогеохимических процессов. На которые, в свою очередь, наибольшее сильное влияние оказывает литологический состав ДО, качественный состав органического вещества и его доступность для восстанавливающих сульфат микроорганизмов. Наличие незамерзающих донных отложений, вследствие отепляющего эффекта термальных вод урочища на его водотоки, накладывает отпечаток на соотношение отдельных форм восстановленной серы в составе их суммы. В донных осадках незамерзающих водотоков увеличение доли лабильного органического вещества и постоянное наличие кислорода приводят к накоплению преимущественно кислоторастворимых сульфидов и элементной серы, в отличие от малопроточных и промерзающих до дна озер, с доминированием в составе восстановленных соединений серы пиритной и органической составляющих.

Работа выполнена в рамках госзадания ФГБУН ФИЦКИА УрО РАН № АААA-A18118012390167-1.
Aвторы благодарныл И.Н. Болотову и С.А. Игловскому за предоставление проб донных осадков, Р.Б. Ивахновой за определение содержания углерода.

\section{Список литературы / References}

1. Malov A.I., Bolotov I.N., Pokrovsky O.S., Zykov S.B., Tokarev I.V., Arslanov K., Druzhinin S.V.,. Lyubas A.A, Gofarov M.Y., Kostikova I.A., Kriauciunas V.V., Chernov S.B., Maksimov F.E., Bespalaya Y., Aksenova O.V. Modeling past and present activity of a subarctic hydrothermal system using $\mathrm{O}$, $\mathrm{H}, \mathrm{C}, \mathrm{U}$ and Th isotopes. Applied Geochemistry. 2015. Vol. 63. P. $93-104$.

2. Функционирование субарктической гидротермальной экосистемы в зимний период/ Под ред. Боголицына К.Г., Болотова И.Н. Екатеринбург: УрО РАН, 2011. 252 с.

Functioning of the subarctic hydrothermal ecosystem in winter. Pod red. Bogolitsyna K.G., Bolotova I.N. Ekaterinburg: UrO RAN, 2011. 252 p. (in Russian).

3. МИ № 88-16365-010-2017. Донные отложения водоемов. Определение гранулометрического состава ситовым и пипеточным методами. Введена 2017-12-26. Архангельск, 2017. 12 с. (in Russian).

4. Dauvalter V.A., Khloptseva E.V. Hydrological and hydrochemical characteristics of the lakes of the Bol'shezemelskaya tundra // Vestnik MGTU. 2008. T. 11. No. 3. P. 407-414 (in Russian).

5. Кокрятская Н.М., Шевченко В.П., Титова К.В., Вахрамеева Е.А., Алиев Р.А., Григорьев В.А., Савельева Л.А., Максимов Ф.Е., Кузнецов В.Ю. Ранний диагенез донных осадков пресноводных озер острова Вайгач // Проблемы Арктики и Антарктики. 2020. Т. 66. № 4. С. 534-554.

Kokryatskaya N.M., Shevchenko V.P., Titova K.V., Vakhrameeva E.A., Aliev R.A., Grigoriev V.A., Savelyeva L.A., Maksimov F.E., Kuznetsov V.Yu. Early diagenesis of bottom sediments of freshwater lakes on Vaigach Island // Problemy Arktiki i Antarktiki. 2020. T. 66. № 4. P. 534-554 (in Russian).

6. Шевченко В.П., Любас А.А., Стародымова Д.П., Болотов И.Н., Аксенова О.В., Алиев Р.А., Гофаров М.Ю., Игловский С.А., Кокрятская Н.М. Особенности геохимии тяжелых металлов в донных осадках малых озер урочища Пымвашор (Большеземельская тундра) // Успехи современного естествознания. 2017. № 1. С. 105-110

Shevchenko V.P., Lyubas A.A., Starodymova D.P., Bolotov I.N., Aksenova O.V., Aliev R.A., Gofarov M.Yu., Iglovsky S.A., Kokryatskaya N.M. Features of the geochemistry of heavy metals in bottom sediments of small lakes in the Pymvashor tract (Bolshezemelskaya tundra) // Uspekhi sovremennogo estestvoznaniya. 2017. № 1. P. 105-110. (in Russian). 